\title{
Camptibia obscura, gen. and sp. n. (Heteroptera: Reduviidae: Harpactorinae) from China
}

\author{
WANZHI $\mathrm{CAI}^{1}$ and MASAAKI TOMOKUNI ${ }^{2}$ \\ ${ }^{1}$ Department of Entomology, China Agricultural University, Yuanmingyuan West Road, Beijing, 100094 China; e-mail: \\ caiwz@cau.edu.cn \\ ${ }^{2}$ Department of Zoology, National Science Museum, Tokyo 3-23-1 Hyakunin-cho, Shinjuku-ku, Tokyo, 169 Japan; e-mail: \\ tomokuni@kahaku.go.jp
}

Key words. Heteroptera, Reduviidae, Harpactorinae, taxonomy, China, new genus, new species, fore legs

Abstract. A new harpactorine reduviid, Camptibia obscura, gen. et sp. n., from China is described. A key to related genera is provided. The functional morphology of the fore legs of this species is discussed.

\section{INTRODUCTION}

The subfamily Harpactorinae is the largest and most poorly studied subfamily of the Reduviidae. More than 300 genera and 2000 species are known (Putshkov \& Putshkov, 1985; Maldonado-Capriles, 1990). Most of the Oriental species of this subfamily are listed in the works of Stål (1874), Distant (1904), Miller (1940, 1948) and Hsiao \& Ren (1981). About 150 valid species of Chinese assassin bugs in 43 genera in this subfamily have been reported prior to this study (Hsiao \& Ren, 1981; Ren, 1988; Cai, 1991, 1995; Putshkov \& Putshkov, 1996; Hua, 2000). During revisionary work on East Asian Reduviidae, we found a remarkable species with strange tibiae. This interesting reduviid can't be placed in any known genus of Reduviidae. So, we have erected a new genus for this species.

\section{Camptibia, gen. $\mathbf{n}$.}

Type species of genus. Camptibia obscura, sp. $\mathrm{n}$. Distribution. China.

Diagnosis. Large sized, elongate. Head distinctly shorter than pronotum (Fig. 1); eyes medium sized, protruding laterally; ocelli widely separated; anteocular portion subequal to postocular portion in length, with a small tubercle posterad to each antennifer; first antennal segment nearly as long as head and pronotum together, third nearly twice as long as second; rostrum robust, first segment the longest and slightly longer than the other two segments (Fig. 4). Anterior pronotal lobe small, slightly sculptured; posterior pronotal lobe nearly twice as long and wide as anterior pronotal lobe; lateral pronotal angles angled, posterior margin of pronotum slightly concave; stridulitrum of subwide, total-striate type (Cai et al., 1994); scutellum unarmed; fore femora medially thickened, mid and hind leg slender; tibiae without spongy fossa, apical 1/3 of fore tibiae distinctly bent (Fig. 2).

Etymology. "Camp" in Greek means bent. The genus is so named because the type species has bent fore tibiae. Feminine.
Remarks. The new genus is similar to Rihirbus Stål (Fig. 3), but the fore tibiae of the new genus never have big teeth-like projections subapically. The structure of the fore tibiae also resembles that in the genus Agyrius Stål, 1863 but the femur of the new genus is not distinctly thickened and the first antennal segment is much longer than the head. It is similar to Villanovanus Distant in general body plan, especially the male, but it belongs to a member of new genus because its fore tibiae are distinctly bent. The new genus resembles Brassivola Distant in the structure of the fore tibia, but the pronotum of the latter have four erect discal spines and lateral pronotal angles have horizontally directed spines. The new genus belongs to the tribe Euagorasini Distant, 1904 (as a division, Euagorasaria) according to Hsiao \& Ren's (1981) as it has an postantennal tubercle and each femur lacks a spine.

\section{A KEY TO THE GENERA MORPHOLOGICALLY SIMILAR TO CAMPTIBIA}

1. Anterior tibia simple, not distinctly incurved ....... 2

- Anterior tibia distinctly incurved ............. 11

2. Anterior lobe of pronotum lacking prominent tubercles on each side $\ldots \ldots \ldots \ldots \ldots \ldots \ldots \ldots \ldots \ldots \ldots \ldots$

- Anterior lobe of pronotum with prominent tubercles on each side ...................... Isyndus Stål, 1858

3. Anterior lobe of pronotum discally spined ........... Bartacus Distant, 1866

- Anterior lobe of pronotum not discally spined ....... 4

4. Posterior lobe of pronotum not discally spined ...... 5

- Posterior lobe of pronotum discally spined ....... 9

5. First rostral segment considerably shorter than second .. 6

- First rostral segment longer than second ......... 7

6. Head with a tubercle behind base of each antenna ....... Euagoras Burmeister, 1835

- Head with a spine behind base of each antenna ........ .................................. 8

7. Head shorter than pronotum ............. 8

- Head nearly as long as pronotum .... Endochus Stål, 1859

8. First antennal segment subequal in length to head plus pronotum ................ Cydnocoris Stål, 1859

- First antennal segment much longer than head plus pronotum ............... Villanovanus Distant, 1904 


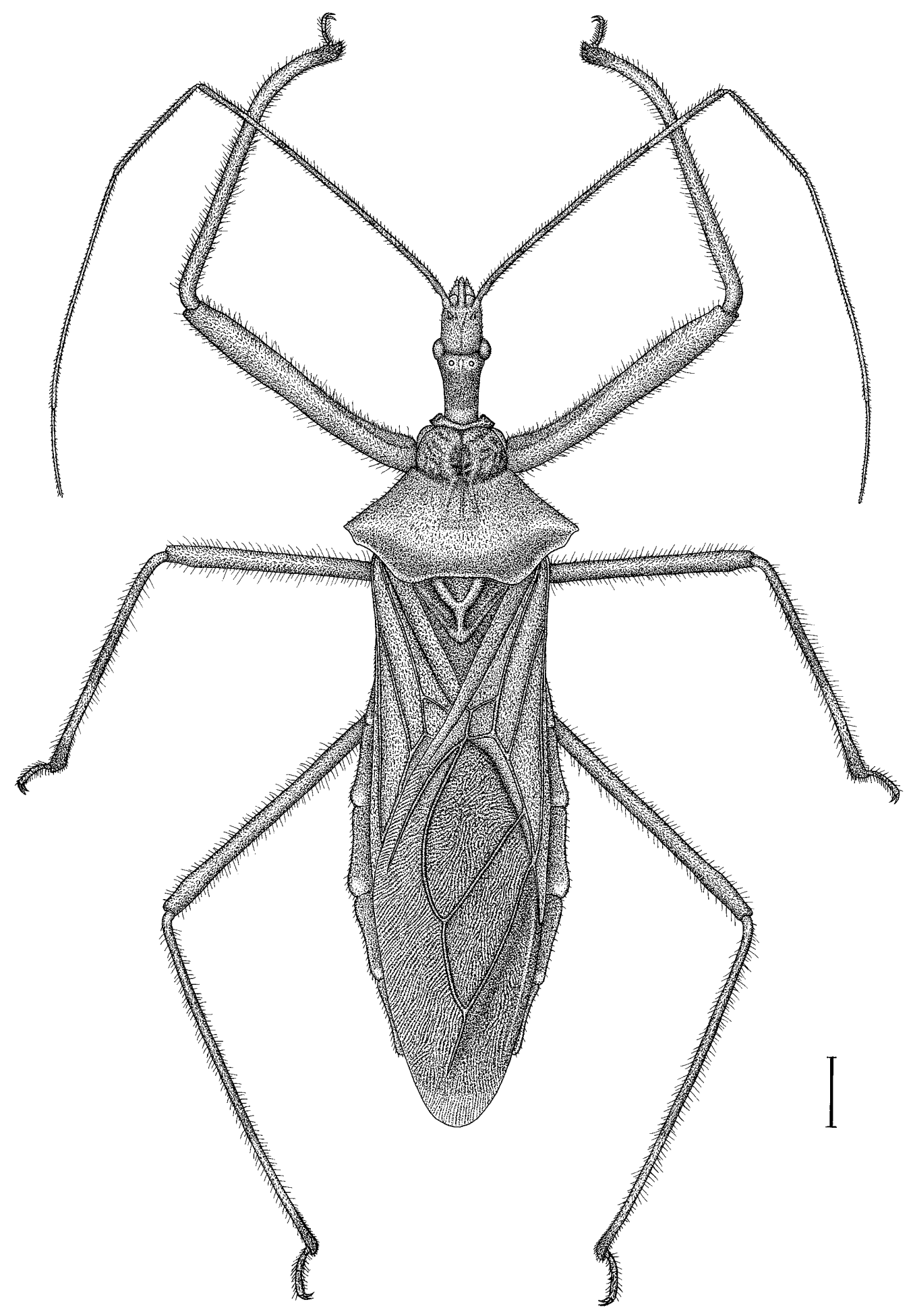

Fig. 1 Camptibia obscura, sp. n., holotype, habitus. Scale: 2 mm.

9. Head about as long as pronotum .. Platerus Distant, 1903

- Head shorter than pronotum ............... 10

10. Head with a spine behind the base of each antenna ...... ......................... Alcmena Stål, 1859

- Head with a tubercle behind the base of each antenna ..... ....................... Epidaus Stål, 1859

11. Anterior tibia spined subapically .... Rihirbus Stål, 1861

- Anterior tibia not spined subapically ........... 12

12. Pronotum spined discally and laterally $\ldots \ldots \ldots \ldots \ldots$ Brassivola Distant, 1904
- Pronotum not spined

Camptibia, gen. $\mathrm{n}$.

Camptibia obscura, sp. n.

(Figs 1-2, Figs 4-12)

Colour. Pale brown, faintly shiny. Head, femora, darker parts of antennae, darker parts of tibiae brown; nnuli on subapical portion of first antennal segments, third (except bases) and fourth antennal segments orange; annuli on basal portion of first antennal segments brownish red; outer surface of basal $1 / 3$ of mid tibiae of 


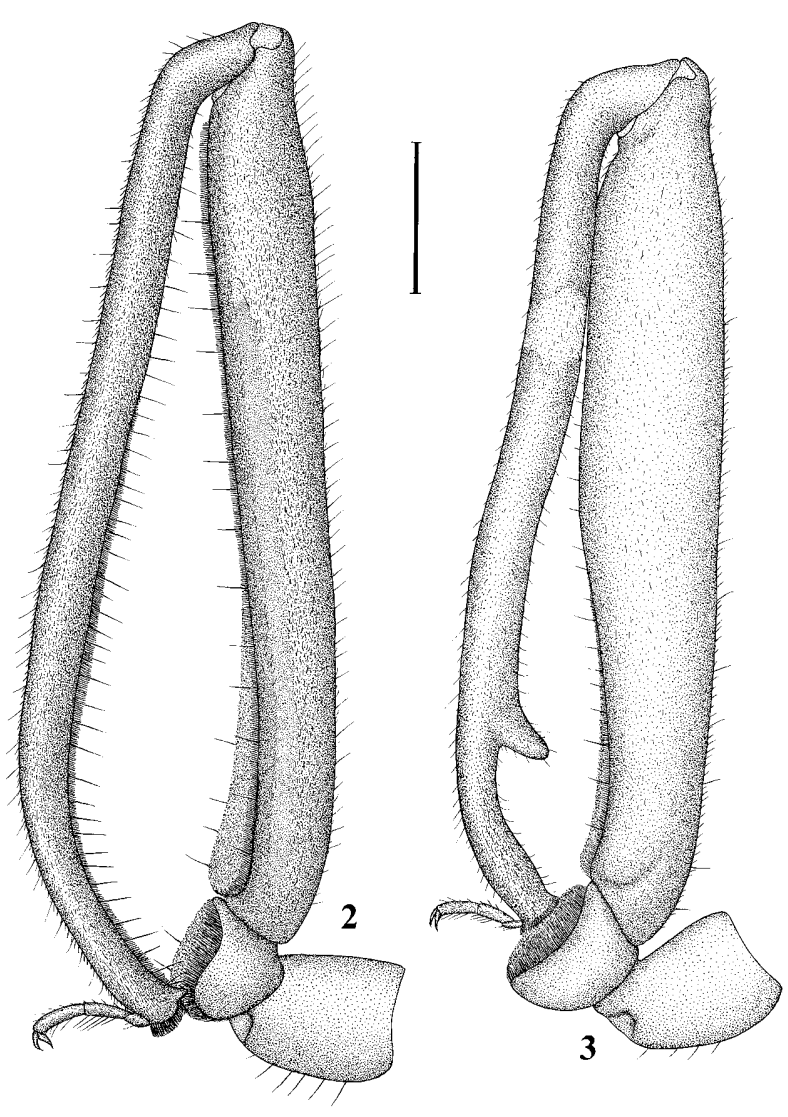

Figs 2-3. Structure of fore leg of two reduviids. 2 Camptibia obscura, sp. n.; 3 - Rihirbus sinicus Hsiao et Ren. Scale: $2 \mathrm{~mm}$. female, bases of mid and hind tibiae, apical 1/4 of mid and hind tibiae (except apices) dark yellow to yellowish brown.

Structure. Body somewhat slender. Body surface (except antennae, eyes, rostrum) clothed with yellowish bent short hairs; lower surface of fore femora and fore trochanters densely clothed with short hairs (Fig. 2); legs bear scattered long hairs. Head nearly cylindrical; first rostral segment slightly longer than combined length of the remaining segments and extending beyond the eyes; first antennal segment of male nearly 2.4 times as long as second, first antennal segment of female about 2.8 times as long as second. Collar process small, not distinct. Anterior half of posterior pronotal lobe with three indistinct longitudinal carinae, lateral pronotal margin nearly rectangular (Fig. 1); fore femur moderately thick, mid and hind femur nearly the same thickness; hemelytron extending beyond abdominal tip. Abdomen of female slightly dilated laterally and that of male not so. Abdominal tip of female is shown in Figs 5, 6. Claspers clavate, distinctly bent, apex slightly thicker (Fig. 10); median pygophore process short, apex rounded (Figs 8, 9). The resting structure of phallus is shown in Figs 1113. Basal plate long, basal plate bridge short and thin; pedicel short and simple. Phallosoma long ovate, dorsal phallothecal sclerite strongly sclerotized, distal portion distinctly wrinkled; struts fused basally and separated distally (Fig. 13). Base of dorsal surface of endosoma with two sclerotized processes (Fig. 14); vesica densely covered with different-sized small processes, with longer ones on the sides.
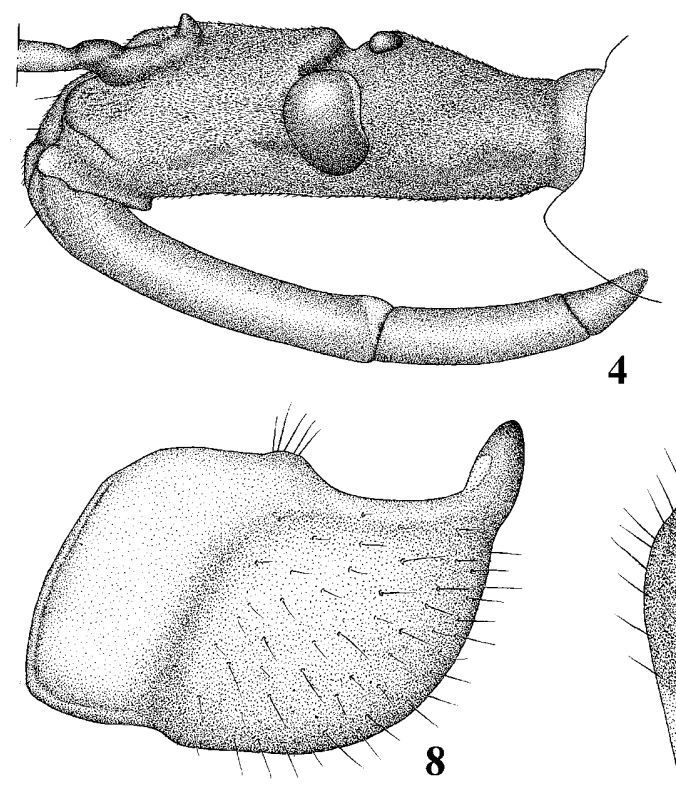
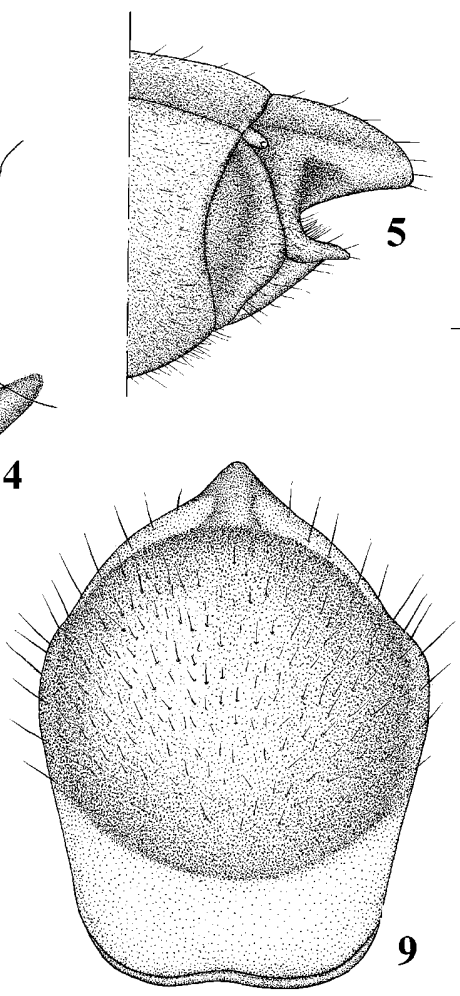
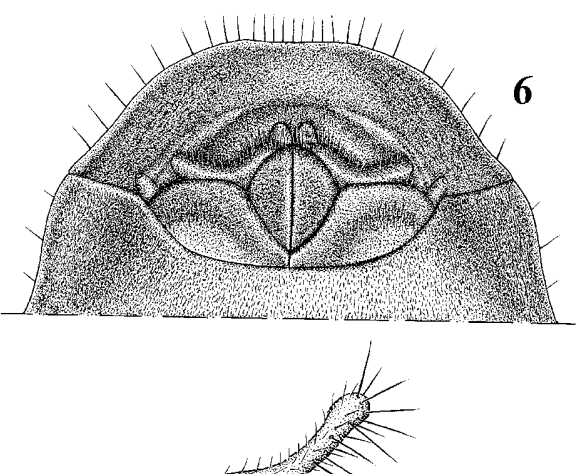

10

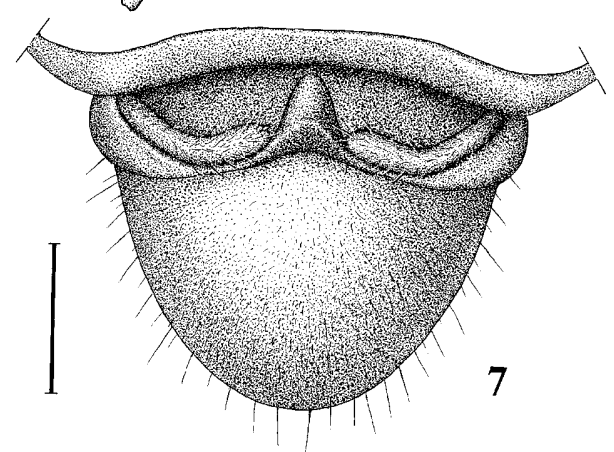

Figs 4-10. Camptibia obscura, sp. n. 4 - head, antennae partly removed; 5-6 - tip of female abdomen; 7 - tip of male abdomen; $8-9$ - pygophore; 10 - left clasper. 4, 5, 8, 10 - lateral view; 6, 9-ventral view; 7 - caudal view. Scale: $1 \mathrm{~mm}$. 


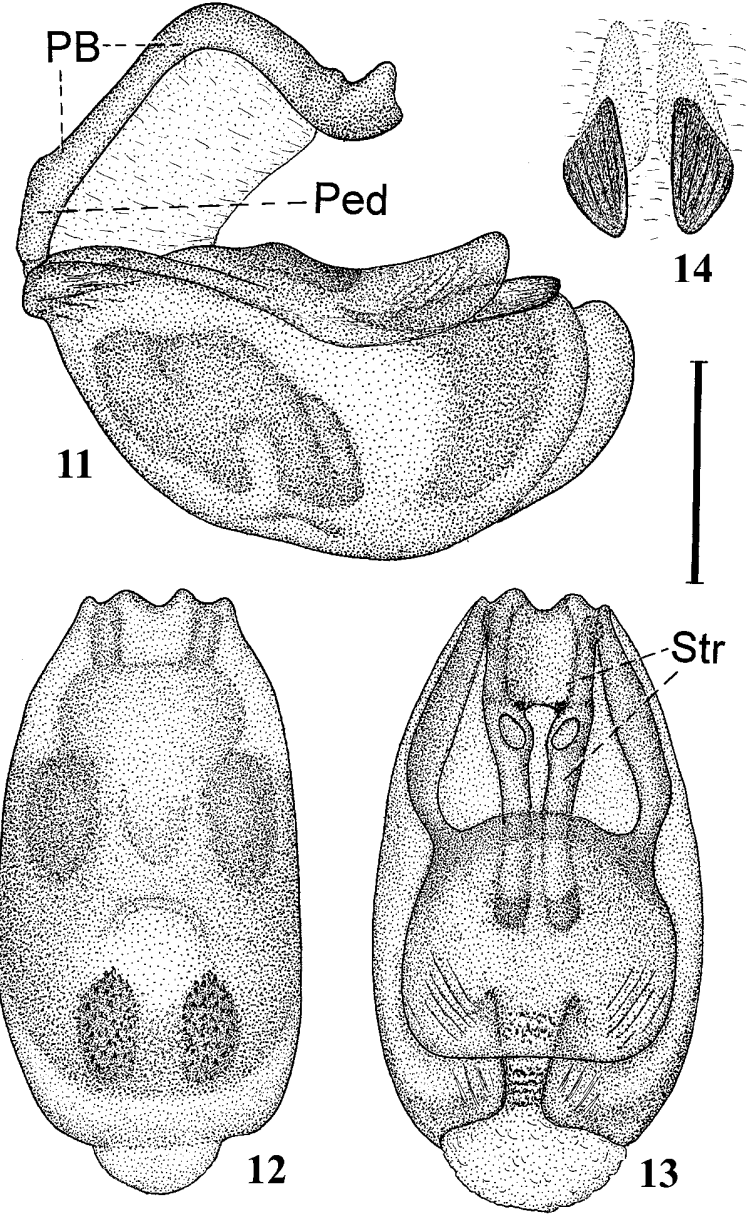

Figs 11-14. Camptibia obscura, sp. n. 11 - phallus; 12-13phallosoma; 14 - vesica processes. 11 - lateral view; 12 - ventral view; 13, 14 - dorsal view. Abbreviations: $\mathrm{BP}$ - basal plate; Ped - pedicel; Str - strut. Scale: $1 \mathrm{~mm}$.

Measurements (mm). Body length 24.1( $\delta$ ), 29.2( $q$ ); maximum width of abdomen $4.53(\hat{\delta}), 7.06(q)$. Head length 3.93(\%), 4.94( + ); length of anteocular part $1.73(\delta), 2.27(q)$; length of postocular part 1.46( $\delta)$, 1.6( $(+)$; length of synthlipsis 1.03( $\delta), 1.23(q)$; distance between ocelli $0.53(\delta), 0.6(\phi)$; length of antennal segments I:II:III:IV= 9.2(ð), 11.47 (q): 3.87(ð), 4.13(q): 8.53(๘), partly missing $(\%): 3.67(\%)$, missing $(q)$; length of rostral segments I:II:III $=2.53(\delta), 3.2(q)$ : 1.41( $\delta)$, 1.93( $(q)$ : $0.6(\delta), 0.68(q)$. Length of anterior lobe of pronotum $1.33(\delta), 1.53(q)$; length of posterior lobe of pronotum 2.8( $\delta), 3.53(\%)$; maximum width of thorax $5.73(\delta), 7.87(q)$; length of scutellum 1.8(๘), 2.2( $q)$; length of hemelytron $15.87(\delta), 19.6(q)$.

Type material. Holotype, $q$; China, Guangxi, Pingxiang, Mt. Daqing; 29.IV.1986; Hua Wei leg; apical two segments of right antenna missing. Paratype, 1 ; same data as holotype. The type specimens will be deposited in the collection of China Agricultural University.

Distribution. China (Guangxi).

Etymology. Name alludes to its dull coloration.

\section{DISCUSSION OF STRUCTURE OF FORE LEG}

The structure of the legs of Reduviidae was surveyed by Miller (1942). Most assassin bugs have raptorial fore legs in broad sense. The femora, tibiae, even trochanters and coxae are often armed with teeth, spines, and hairs. In a large number of species of Reduviidae, the lower surface of the apical portion of fore tibiae bears a so-called "spongy fossa", a pad of specialized setae (= fossula spongiosa), which enhances the gripping capacity of the legs during the capture of prey. But no the member of the Harpactorinae has a spongy fossa. In Camptibia, nearly the whole length of lower surface of the femur is covered with short hairs and scattered longer hairs. The lower surface of the fore tibia is covered with scattered erect hairs and the apical $2 / 3$ covered with short erect hairs. The lower surface of the fore trochanter, basal $2 / 5$ of the lower surface of fore femur and apex of fore tibia is densely covered with erect short hairs similar to those on the spongy fossa of other reduviids, but the areas of cuticle covered by dense hairs are not less sclerotized than the remaining areas. Similar pubescence is also found on the legs of species belonging to the genus Rihirbus Stål (Fig. 3) and even of some species of Belostomatidae and Nepidae. Comparing the fore leg structure in Camptibia gen. nov. and Rihirbus we conclude that Camptibia gen. nov. can possibly more effectively hold on to big and smoother prey than Rihirbus Stål, 1861.

ACKNOWLEDGEMENTS. This research was supported by the National Natural Science Foundation of China (No. 39970091, No. 30070518) and The Natural Science Foundation of Beijing (No. 6992018) to Cai and Nakayama Foundation grant to Tomokuni. We are very grateful to Zhihong Zhou, Zhuyin Wang and Tao Zeng of Institute of Plant Protection, Agricultural Academy of Guangxi Zhuang Nationality Autonomous Region for kindly supplying material for this study.

\section{REFERENCES}

CAI W. 1991: Genus Homalosphodrus Stål found in China. Entomotaxonomia 13: 284.

CAI W. 1995: Yangicoris, a new genus of Dicrotelini (Heteroptera: Reduviidae: Harpactorinae) from China. Entomotaxonomia 17(Suppl.): 1-5.

CAi W., Zhou Y. \& Lu J. 1994: The morphology, postembryonic development and evolution of stridulitra in Reduviidae (Heteroptera: Reduvioidea), with special reference to their taxonomic importance. Entomol. Sinica 1: 1-16.

Distant W.L. 1903-1904: The Fauna of British India, Including Ceylon and Burma. Rhyn. 2. Taylor \& Francis, London, pp. 196-403. (1903: 1-242; 1904, i-xvii, 243-503).

Hsiao T.-Y. \& Ren S.-Z. 1981: Reduviidae. In: Hsiao et al.: $A$ Handbook for the Determination of the Chinese HemipteraHeteroptera (II). Science Press, Beijing, pp. 390-538.

Hua L. 2000: List of Chinese Insects, Vol. I. Zhongshan University Press, Guangzhou, pp. 206-221.

Maldonado-Capriles J. 1990: Systematic Catalogue of the Reduviidae of the World (Insecta: Heteroptera). A special edition of Caribbean Journal of Science, Puerto Rico, 694 pp.

Miller N.C.E. 1940: New genera and species of Malaysian Reduviidae. Part I. J. F.M.S. Mus. 18: 419-599.

Miller N.C.E. 1942: On the structure of the legs in Reduviidae (Rhynchota). Proc. Roy. Entomol. Soc. London (A) 17: 49-58. 
Miller N.C.E. 1948: New genera and species of Reduviidae from The Philippines, Celebes and Malaysia. Trans. Roy. Entomol. Soc. London 99: 411-473.

Putshion V.G. \& Putshiov P.V. 1985: A Catalogue of Assassin-Bugs Genera of the World (Heteroptera: Reduviidae). VINITI, Moskva, $138 \mathrm{pp}$.

Putshkov V.G. \& Putshkov P.V. 1996: Family Reduviidae Latreille, 1807 - assassin-bugs. In: Aukema B. \& Rieger C. (eds.): Catalogue of the Heteroptera of Palaearctic Region,
Vol. 2. The Netherlands Entomological Society, Amsterdam, pp. 148-265.

ReN S.-Z. 1988: Hemiptera: Reduviidae, Enicocephalidae, Isometopidae, Nabidae, Berytidae, Coreidae. In: Huang, F.-S. (ed.): Insects of Mt. Namjagbarwa Region of Xizang. Science Press, Beijing, pp. 105-120.

STÅL C. 1874: Enumeratio Hemipterorum. 4. K. Svenska VetenskAkad. Handl. (N. F.) 11: 1-182.

Received June 5, 2002; revised July 25, 2002; accepted October 17, 2002 